UDC 531/534/: [57+61]

doi: https://doi.org/10.15407/ubj92.01.084

\title{
PHENOL-OXIDIZING ACTIVITY AND FATTY ACID PROFILE OF Brevibacillus centrosporus F14 STRAIN
}

\author{
T. V. GUDZENKO, O. V. VOLIUVACH, O. G. GORSHKOVA, \\ A. M. OSTAPCHUK, V. O. IVANYTSIA \\ I.I. Mechnykov Odessa National University, Ukraine; \\ e-mail:tgudzenko@ukr.net
}

Received: 19 June 2019; Accepted: 29 November 20192019

\begin{abstract}
Biotechnological treatment of enterprises wastewater, which contains toxic phenolic compounds, is the most acceptable method today. Therefore, the search for new non-pathogenic biochemically active microorganisms - destructors of phenol and their identification is relevant. The aim of this study was to determine phenol-oxidizing activity and the fatty acid profile of Brevibacillus centrosporus F14 - destructor of phenol, isolated from pharmaceutical plant wastewater. Fatty acids analysis of the microorganism culture was carried out using automatic system of microorganisms identification MIDI Sherlock based on gas chromatograph Agilent 7890. The phenol-oxidizing activity of bacteria was determined by photometric method according to the degree of phenol extraction from the water. It was experimentally confirmed that Brevibacillus sp. F14 strain had a phenol-destructive activity. When phenol-containing water was treated with Brevibacillus sp. F14 cells, phenol concentration in the water decreased from $200.0 \pm 12.0 \mathrm{mg} / \mathrm{l}$ to $6.8 \pm 0.8 \mathrm{mg} / \mathrm{l} \mathrm{during} 15$ days of exposure. Chromatographic analysis showed that saturated fatty acids i-14:0 (14.9\%), i-15:0 (14.8\%), a-15:0 (34.9\%), i-16:0 (11.10\%) dominated in the strain's fatty acids profile. The total content of the branched saturated fatty acids $i-14: 0, i-15: 0, a-15: 0, i-16: 0, i-17: 0, a-17: 0, \sum(a-17: 1 / i-17: 1)$ was $85.0 \%$ and that of saturated and unsaturated fatty acids with the normal structure $-7 \%$ of the total fatty acids pool. The distinction of Brevibacillus centrosporus F14 strain's fatty acid profile from other bacteria of Brevibacillus genus was the presence of more $i-14: 0$ (14.85\%), i-16:0 (11.10\%) fatty acids and 16: $1 \mathrm{w} 7 \mathrm{c}$ alcohol (7.71\%), as well as the minor content of fatty acids markers 16:0 $\mathrm{N}$ alcohol (0.60\%), 18:3 w6c (0.4\%) and $\sum(a-17: 1 / \mathrm{i}-17: 1)(1.94 \%)$. According to the phenotypic characteristics and fatty acid composition, the tested phenol-oxidizing strain belongs to Brevibacillus centrosporus species. The index of Brevibacillus centrosporus F14 strain's fatty acid profile similarity with the library was 0.645 .
\end{abstract}

Ke ywords: Brevibacillus centrosporus, destructor of phenol, identification, composition of fatty acids.

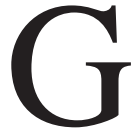

ram-positive bacteria of the genus Brevibacillus are widespread in various habitats [1]. They are characterized by a high growth rate, better transformation efficiency using electroporation, the presence of transport vectors, the production of a small amount of extracellular protease and the constitutive expression of heterologous proteins [1]. Representatives of this genus are of great biotechnological interest - they are a source of various enzymes, antitumor peptides, and are capable of biodegrading polyethylene [1, 2]. The authors of [3] indicate that the strain Brevibacillus borstelensis AK1 has the genes for the decom- position of a wide range of substrates, including polyethylene (plastic) and long-chain hydrocarbons. These genomic features may be useful for future environmental/biotechnological applications. Brevibacillus borstelensis has great potential to destroy carbendazim fungicide in crops and crops at a high rate, especially in combination with Streptomyces albogriseolus. The lipolytic strain of Brevibacillus borstelensis SH168 may enhance the conversion of food waste into bio-fertilizer.

It is known that the bacterial strains, Brevibacillus centrosporus and Paenibacillus azoreducens (have been isolated from the sludge samples col-

(C) 2020 Gudzenko T. V. et al. This is an open-access article distributed under the terms of the Creative Commons Attribution License, which permits unrestricted use, distribution, and reproduction in any medium, provided the original author and source are credited. 
lected from Textile Industry, Bhaluka, Bangladesh) have the abilities to degrade Reactive Violet 5R. The decolourization rate was different for the different concentrations of the same dye. Brevibacillus centrosporus displayed a decolorization rate of $94.55 \%$, 90.79\%, 91.17\% when inoculated and incubated in an SM broth containing the azo dye reactive violet $5 \mathrm{R}$ at $1 \%(\mathrm{v} / \mathrm{v}), 3 \%(\mathrm{v} / \mathrm{v})$ and $5 \%(\mathrm{v} / \mathrm{v})$ concentrations respectively for a consecutive 5 days [4].

Fatty acid composition of total cellular lipids as important species and intraspecific chemotaxonomic characteristics correlates with the results of molecular genetics indicators' identification $[5,6]$. For microorganisms, it is used as the chemotaxonomic feature that allows identification of microorganisms using fatty acid profiles' libraries [7].

It is known that the FAME data have diagnostic value for a few Brevibacillus species [8]. Some differences in the fatty acid profile of six species of the bacteria of the genus Brevibacillus: Brevibacillus agri, Brevibacillus borstelensis, Brevibacillus lateosporus, Brevibacillus parabrevis, Brevibacillus choshinensis and Brevibacillus invocatus, are presented in [8]. For the last two species, the mean of the ratio a-15:0 versus i-15:0 was above 3.0, while for the other four species it was, at most, 1.0. Furthermore, Brevibacillus borstelensis and Brevibacillus parabrevis could be discriminated from these other species by having much lower amounts of i-14:0 (below 4\%). Finally, Brevibacillus laterosporus showed less than $1 \%$ of $16: 1$ w7c alcohol while all others had at least $2 \%$ or more of this component [8].

Thus, closely related microorganisms are clearly distinguished by the presence and percentage of fatty acids in the composition of their cellular lipids. Particular attention is paid to the search for new nonpathogenic microorganisms intended for the purification of wastewater from the production of pharmaceuticals, medical institutions with a predominant content of toxic phenolic and other cyclic aromatic compounds in them [9].

The aim of this study was to determine the phenol-oxidizing activity and the fatty acid profile of Brevibacillus centrosporus F14 - destructor of phenol, isolated from wastewater pharmaceutical plant.

\section{Materials and Methods}

The object of the study was the bacterial strain Brevibacillus sp. F14 isolated in 2017 (the southern region of Ukraine) from the wastewater of a pharmaceutical plant.
Bacteria were cultured on Tryptic soy agar (Merck, Germany) at $28 \pm 1{ }^{\circ} \mathrm{C}$ for $24 \mathrm{~h}$. Cellular fatty acids (FAs) were saponified, methylated and extracted according to the protocol of the Sherlock Microbial Identification system (version 6.21; MIDI) and FAs methyl esters profile was determined by gas chromatography by referencing the STBA6 Microbial Identification System (MIS) standard library [10].

To analyze the composition of cellular lipids, one complete loop of wet biomass was placed in glass vials for further chemical lysis of cells and saponification of the lipids of the test organism. Saponification was performed by adding 50\% methanol and $3.7 \mathrm{M} \mathrm{NaOH}$.

The prepared sample was kept for $30 \mathrm{~min}$ at 95-100 ${ }^{\circ} \mathrm{C}$. Fatty acid methylation was carried out by heating the reaction mixture at $80^{\circ} \mathrm{C}$ for $10 \mathrm{~min}$ after adding a solution of acidic methanol. Extracted methyl esters of fatty acids were neutralized with a $0.3 \mathrm{M}$ solution of $\mathrm{NaOH}$ [11].

Samples of $2 \mathrm{ml}$ volume were transferred into the evaporator in the mode split with a coefficient 40:1, evaporator's temperature $-250^{\circ} \mathrm{C}$. The separation was carried out in temperature programming mode - initial temperature of $170{ }^{\circ} \mathrm{C}$ with a gradient of $5^{\circ} \mathrm{C} / \mathrm{min}$ to $270{ }^{\circ} \mathrm{C}$.

Chromatographic separation of methyl FA esters was conducted at Agilent 7890 gas chromatograph (Agilent Technologies, USA) with a capillary column ULTRA 2 and flame ionization detector. Fatty acid content was expressed as a percentage to the total sum of peaks' squares.

Evaluation of the phenol-oxidizing activity of free bacterial cells of Brevibacillus sp. F14 was carried out according to the degree of extraction of phenol from water $(\alpha, \%)$, which was calculated by the equation:

$$
\alpha=\left[\left(\mathrm{C}_{0}-\mathrm{C}\right) / \mathrm{C}_{0}\right] \cdot 100 \%,
$$

where $\mathrm{C}_{0}$ and $\mathrm{C}$ are concentrations of phenol in water before $(200 \mathrm{mg} / \mathrm{l})$ and after treatment.

The concentration of phenol in the control and experimental samples before and after treatment was determined by a photocolorimetric method based on the formation of colored phenol compounds with 4 -aminoantipyrine in the presence of potassium hexacyanoferrate (III) at $\mathrm{pH} 10.0 \pm 0.2$ [12].

The significance of differences between the mean values of the residual concentration of phenol in water was determined by the Student's criterion 
at a significance level of at least $95 \%(P \leq 0.05)$. Five series of tests $(n=5)$ were conducted.

Data processing was carried out using the program Microsoft Office Excel (2003).

\section{Results and Discussion}

Preliminary studies have shown that, on the basis of the morphological, molecular-biological and biochemical properties of the strain F14, identified as Brevibacillus sp. F14, had destructive activity against $\mathrm{N}$-cetylpyridinium bromide $[9,13]$.

The results of the evaluation of the phenol-oxidizing ability of the test bacterial culture of Brevibacillus sp. F14 are presented in Table 1. As a result of research, it was found that with a single injection of free cells of the strain of Brevibacillus sp. F14 in the amount of $5.5 \times 10^{5} \mathrm{CFU} / \mathrm{ml}$ in the water contaminated with phenol on the $8^{\text {th }}$ day of exposure, the concentration of phenol in water decreased from $200.0 \pm 12.0 \mathrm{mg} / \mathrm{l}$ to $66.0 \pm 4.7 \mathrm{mg} / \mathrm{l}$ (the degree of phenol extraction from water is $67 \%)$. On the $8^{\text {th }}$ day of exposure, the degree of excretion of phenol from water increased to $86 \%$, reaching a maximum of $97 \%$ for 15 days.

To clarify the species of the test strain Brevibacillus sp. F14 was studied the fatty acid composition of the cell wall of bacteria - destructor of phenol.

The fatty acid composition of the studied phenol-oxidizing strain with a high similarity index (Sim Index $=0.645$ ) was identified as Brevibacillus centrosporus F14. The interpretation of the obtained chromatograms for the fatty-acid profile of the strain Brevibacillus centrosporus $\mathrm{F} 14$ is presented in Table 2. The absence of chemical markers of hydroxy acids in their fatty acid profile indicates the attribution of this strain to gram-positive bacteria. In the spectrum of fatty acids of total cellular lipids of the test strain, no peaks corresponding to the series of 2- and 3-hydroxy acids from the composition of the biomass were found.

As a result of the analysis of the fatty acid profile of the strain Brevibacillus centrosporus F14 was total detected 17 fatty acids with 12 to 18 carbon atoms, mostly branched structure (Table 2). The total fatty acid content (saturated and unsaturated) of the branched structure was $85 \%$ of the total fatty acid pool found on the chromatograms. The 12-methyltetradecanoic acid a-15:0 was dominant, the mole fraction of which was $34.89 \%$. The main fatty acids of the strain Brevibacillus centrosporus F14 include fatty acids i-14:0 (14.85\%), a-15:0 (34.89\%), i-15:0
Table 1. Phenol-oxidizing ability of the test strain Brevibacillus sp. F14

\begin{tabular}{c|c}
\hline Day & $\begin{array}{c}\text { The concentration of phenol } \\
\text { in the water, } \mathrm{mg} / \mathrm{l}\end{array}$ \\
\hline 0 & $200.0 \pm 12.0$ \\
3 & $164.0 \pm 12.0$ \\
6 & $112.0 \pm 8.7$ \\
8 & $66.0 \pm 4.7$ \\
10 & $28.0 \pm 2.1$ \\
13 & $7.20 \pm 0.81$ \\
15 & $6.8 \pm 0.8$ \\
\hline
\end{tabular}

Note: $P \leq 0.05$; concentration of phenol in water before using bacteria $-200.0 \pm 12.0 \mathrm{mg} / \mathrm{l}$; concentration of bacterial cells is $5.5 \times 10^{5} \mathrm{CFU} / \mathrm{ml}(M \pm m, n=5)$.

(14.81\%), i-16:0 (11.10\%), characteristic of bacteria of the genus Brevibacillus [14]. The fatty acid profile of Brevibacillus centrosporus F14 was similar to that of other Brevibacillus species, but differed from them, as were the strains of Brevibacillus limnophilus sp. nov. DSM 6472 (12.40\%) [15], Brevibacillus invocatus JCM 12215T (7.9\%) [16], with a high content of i-16:0 fatty acid. For example, in the fatty acid profile of the strain Brevibacillus agri NBRC 15538T, the i-16:0 fatty acid was recorded in an amount up to $2 \%$ [16]. It is important to note that the authors of work [17], when identifying a denitrifying bacterium isolated from the soil of a ginseng field in the province of Pocheon in South Korea, showed that the fatty acid profile of the strain Gsoil 3088T mainly included i-15:0 (36.3\%), i-14:0 (15.0\%) and a-15:0 (14.8\%). These chemotaxonomic data confirm the belonging of the strain Gsoil 3088T to the genus Brevibacillus.

In the fatty acid profile of the strain Brevibacillus centrosporus F14, 7 fatty acids (saturated and unsaturated) branched structures in the form -iso and -anteiso: i-14:0 (14.85\%), i-15:0 (14.81\%), a-15:0 (34.89\%), i-16:0 (11.10\%), i-17:1 w10c (1.29\%), i-17: 0 (1.38\%), a-17:0 (4.91\%); and $\sum$ (a-17:1/i-17:1) (1.94\%). The results are presented in Fig. 1.

It should be noted that on the chromatograms of the strain of Brevibacillus centrosporus F14 we studied were not recorded even in trace amounts of fatty acid i-15:1 w9c, isomers of saturated fatty acids of branched structure: i-13:0 and a-13:0 anteiso, which are characteristic of pathogenic bacteria Brevibacillus agri NBRC 15538T, Brevibacillus invocatus JCM 12215T, causing waterborne diseases [16]. 
Table 2. The composition of cellular fatty acids (\%) of the test strain Brevibacillus centrosporus F14 and other strains of bacteria of the genus Brevibacillus, presented in the literature [16]

\begin{tabular}{|c|c|c|c|c|}
\hline \multirow[b]{2}{*}{ Fatty acid } & \multicolumn{4}{|c|}{$\%$ to the total sum of peak areas } \\
\hline & Br. centrosporus F14 & $\begin{array}{l}\text { Br. centrosporus } \\
\text { NBRC } 15540^{\mathrm{T}}[16]\end{array}$ & $\begin{array}{c}\text { Br.agri } \\
\text { NBRC } \\
15538^{\mathrm{T}}[16]\end{array}$ & $\begin{array}{l}\text { Br. invocatus } \\
\text { JCM } 12215^{\mathrm{T}}[16]\end{array}$ \\
\hline 10:0 & nd & 1.0 & 0.2 & nd \\
\hline $12: 0$ & 0.68 & nd & nd & nd \\
\hline$i-13: 0$ & nd & nd & 0.5 & 0.4 \\
\hline a-13:0 & nd & nd & nd & 0.1 \\
\hline i-14:0 & 14.85 & 1.5 & 1.7 & 10.7 \\
\hline 14:0 & 0.41 & 0.4 & 0.5 & 0.2 \\
\hline $\mathrm{i}-15: 0$ & 14.81 & 12.0 & 39.1 & 22.4 \\
\hline $\mathrm{a}-15: 0$ & 34.89 & 72.6 & 41.7 & 44.6 \\
\hline $15: 0$ & nd & nd & nd & 1.1 \\
\hline i-15:1 w9c & nd & 2.2 & 2.0 & 6.4 \\
\hline 16:1 w7c alcohol & 7.71 & 1.0 & 1.3 & 0.7 \\
\hline 16:0 $\mathrm{N}$ alcohol & 0.60 & nd & nd & nd \\
\hline $\mathrm{i}-16: 0$ & 11.10 & 1.5 & 1.9 & 7.9 \\
\hline 16:1 w11c & 2.97 & 0.8 & 3.9 & 1.5 \\
\hline $16: 0$ & 2.03 & 0.9 & 0.7 & 0.1 \\
\hline i-17:1 w10c & 1.29 & 1.3 & 2.5 & 1.3 \\
\hline$\sum(\mathrm{a}-17: 1 / \mathrm{i}-17: 1)$ & 1.94 & nd & nd & nd \\
\hline $\mathrm{i}-17: 0$ & 1.38 & 1.1 & 1.8 & 1.0 \\
\hline $\mathrm{a}-17: 0$ & 4.91 & 3.6 & 1.4 & 1.4 \\
\hline $18: 3$ w6c & 0.43 & nd & nd & nd \\
\hline Unknown & - & - & 0.5 & 0.5 \\
\hline$\sum \mathrm{FA}_{\text {unsaturated }}$ & 14.94 & 4.1 & 9.7 & 9.9 \\
\hline$\sum \mathrm{FA}_{\text {saturated }}$ & 85.06 & 95.8 & 85.8 & 85.6 \\
\hline Saturation coefficient & 5.7 & 23.4 & 8.8 & 8.6 \\
\hline Total & 100 & 99.9 & & \\
\hline
\end{tabular}

Note: "nd" - fatty acid not detected

The total percentage of saturated and unsaturated fatty acids of normal structure in the fatty acid profile of strain Brevibacillus centrosporus F14 was 7\%: 12:0 (0.68\%), 14:0 (0.41\%), 16:1 w11c (2.97\%), $16: 0$ (2.03\%), 18:3 w6c (0.43\%); the maximum was hexadecenoic acid - 16:1 w11c (2.97\%) (Fig. 2).

Of interest is the fact that the Brevibacillus centrosporus F14 strain contained the maximum amount of $16: 1 \mathrm{w} 7 \mathrm{c}$ alcohol $(\mathrm{w}=7.71 \%)$ in the composition of cellular lipids compared with bacteria of the genus Brevibacillus (Brevibacillus agri NBRC
15538T, Brevibacillus invocatus JCM 12215T), and with bacteria of a similar species Brevibacillus centrosporus NBRC 15540T, studied in [16]. From the bacteria listed above, the strain studied by us differs in the presence of 1-hexadecanol 16:0 $\mathrm{N}$ alcohol and 18:3 w6c fatty acid ((6Z, 9Z, 12Z) -6,9,12-octadecatrienoic acid) in its fatty acid profile recorded in a minor the amount of $0.60 \%$ and $0.43 \%$ respectively $[15,16]$. The biomarker ratio [a-15:0/i-15:0] for the Brevibacillus centrosporus F14 strain was 2.36, which exceeded the biomarker ratio [a-15:0/i-15:0] 


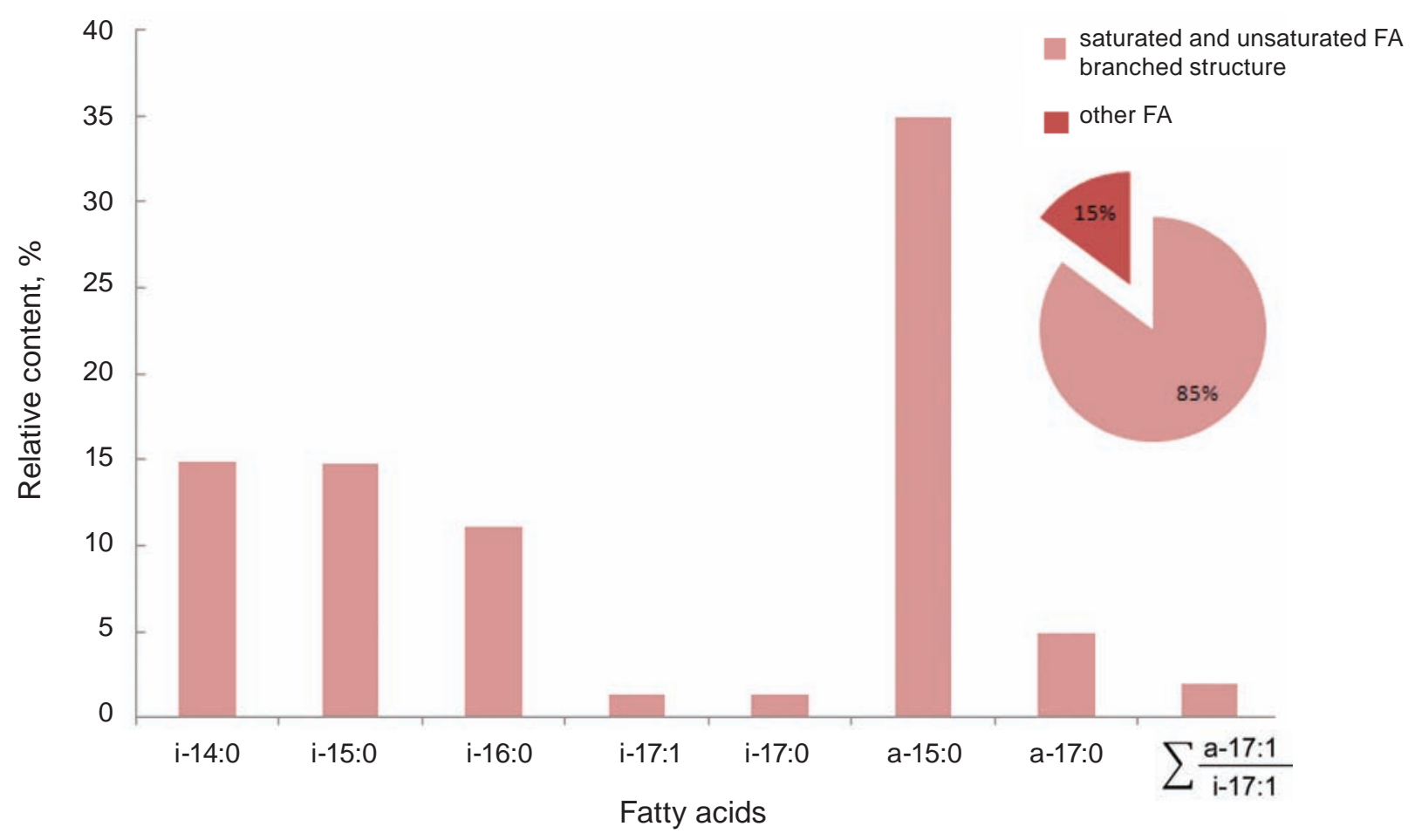

Fig. 1. Relative content (\%) of saturated and unsaturated branched fatty acids in the fatty acid profile of the test strain Brevibacillus centrosporus F14

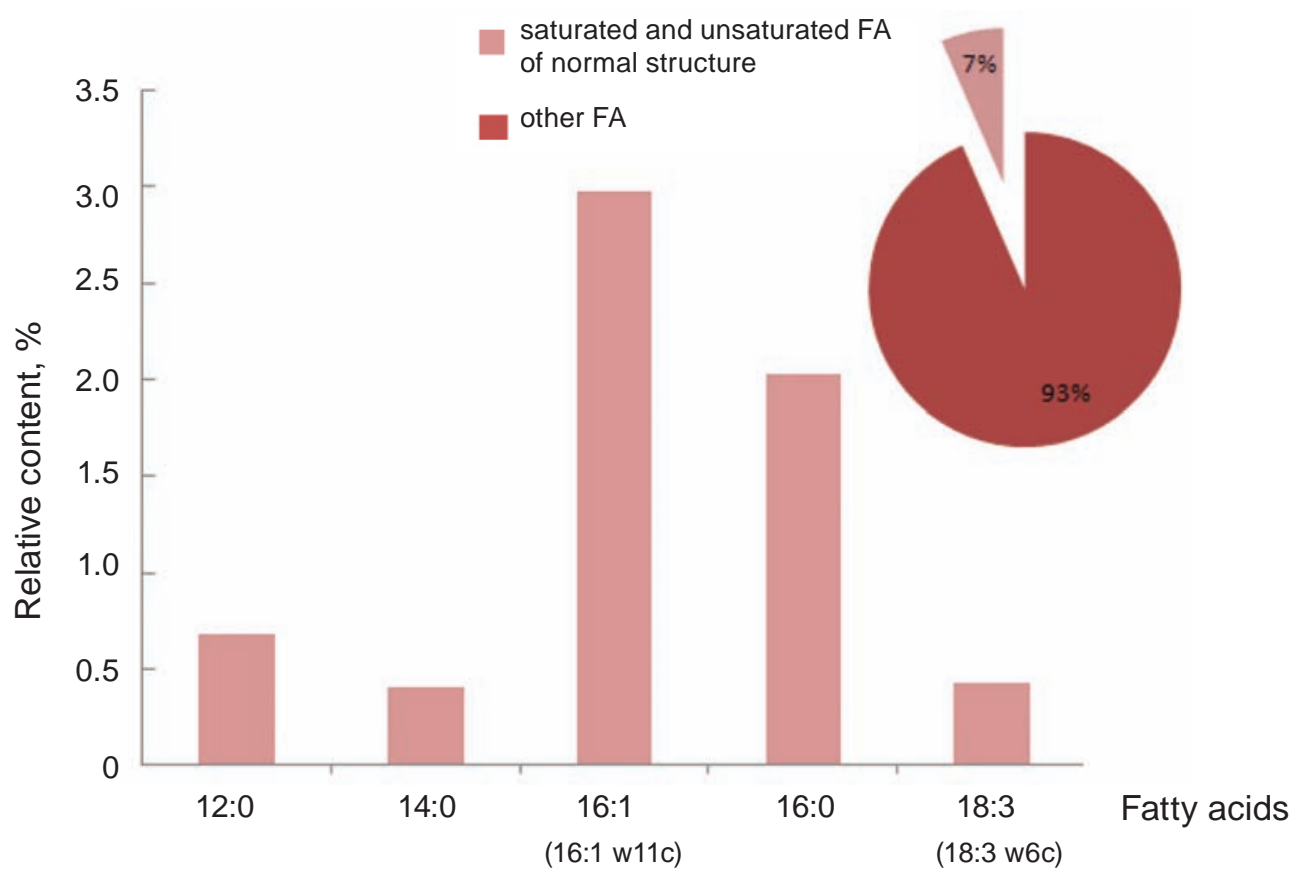

Fig. 2. Relative content (\%) of saturated and unsaturated fatty acids of normal structure in the fatty acid profile of strain Brevibacillus centrosporus F14. 
$\leq 1.0$ for Brevibacillus agri, and was significantly less compared to $[\mathrm{a}-15: 0 / \mathrm{i}-15: 0]=6.05$ for the strain Brevibacillus centrosporus NBRC 15540T, studied by the authors of [16].

From the data presented in Table 1 it can be seen that at the species level, the strain of Brevibacillus centrosporus F14 that we study differs from other strains of the genus Brevibacillus by the saturation coefficient (saturation coefficient $\left(\sum \mathrm{FA}_{\text {saturation,\% }} / \mathrm{FA}_{\text {unsaturation,\% }}\right.$. It is 5.7 for the strain Brevibacillus centrosporus F14-destructor of phenol and for the strains Brevibacillus agri NBRC 15538T, Brevibacillus invocatus JCM 12215T [16] 1.5 times higher and ranges from 8.6 to 8.8.

Thus, according to the composition of fatty acids of cellular lipids a non-pathogenic phenoloxidizing bacterial culture using the RTSBA6 6.21 MIDI Sherlock high-similarity index program (Sim Index $=0.645$ ) was identified as Brevibacillus centrosporus F14. The identified features of the spectrum of fatty acids of the studied microorganism isolated from the wastewater of a pharmaceutical plant are systematized and distinguish it from other bacteria of the genus Brevibacillus. The studied strain replenished the museum collection of non-pathogenic microorganism strains of the Department of Microbiology, Virology and Biotechnology of the Odesa National I.I. Mechnykov University - Brevibacillus centrosporus F14 [9].

Thus, it has been experimentally confirmed that a strain Brevibacillus centrosporus F14, isolated from the wastewater of a pharmaceutical plant, has a phenol-destructive activity. When treating phenol-containing water with free cells of Brevibacillus centrosporus F14 phenol concentration in water decreased from $200 \pm 12.0 \mathrm{mg} / \mathrm{l}$ to $6.8 \pm 0.8 \mathrm{mg} / \mathrm{l}$ during 15 days of exposure. According to the composition of fatty acids in cellular lipids the test non-pathogenic phenol-oxidizing strain using the RTSBA6 6.21 MIDI Sherlock high-similarity index program (Sim Index $=0.645)$ was identified as Brevibacillus centrosporus F14. Chromatographic analysis showed that saturated fatty acids prevailed in the composition of fatty acids of cellular lipids of the test strain: i-14:0 (14.9\%), i-15:0 (14.8\%), a-15:0 (34.9\%), i-16:0 (11.10\%), which are characteristic of bacteria of the genus Brevibacillus. In the fatty acid profile of the phenol-oxidizing strain Brevibacillus centrosporus F14 are absent even in trace amounts fatty acid i-15:1 w9c and isomers of saturated fatty acids of branched structure: i-13:0 and a-13:0, characteristic of pathogenic bacteria Brevibacillus agri NBRC 15538T, Brevibacillus invocatus JCM 12215T. At the species level the strain Brevibacillus centrosporus F14 that we study differs from other strains of the genus Brevibacillus by the saturation coefficient

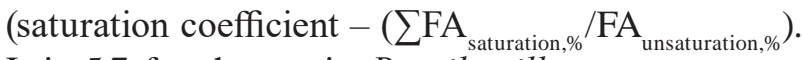
It is 5.7 for the strain Brevibacillus centrosporus F14-destructor of phenol, and for the strains Brevibacillus agri NBRC 15538T, Brevibacillus invocatus JCM $12215 \mathrm{~T} 1.5$ times higher and ranges from 8.6 to 8.8. The peculiarities of the fatty acid profile of the strain Brevibacillus centrosporus F14 studied by us from others bacteria of the genus Brevibacillus is the presence of more fatty acids in i-14:0 (14.85\%), i-16:0 (11.10\%), 16:1 w7c alcohol (7.71\%), as well as the presence in the minor amount of marker fatty acids - 16:0 $\mathrm{N}$ alcohol (0.60\%), 18:3 w6c (0.4\%) and the sum $\sum(\mathrm{a}-17: 1 / \mathrm{i}-17: 1)(1.94 \%)$.

Conflict of interest. Authors have completed the Unified Conflicts of Interest form at http://ukrbiochemjournal.org/wp-content/uploads/2018/12/ coi_disclosure.pdf and declare no conflict of interest.

\section{ФЕНОЛОКИСЛЮВАЛЬНА АКТИВНІСТЬ I ЖИРНО- КИСЛОТНИЙ ПРОФІЛЬ ШТАМУ Brevibacillus centrosporus F14}

\author{
Т. В. Гудзенко, О. В. Волювач, \\ О. Г. Горикова, А. М. Остапчук, \\ В. О. Іваниця
Одеський національний університет імені I.I. Мечникова, Україна; e-mail: tgudzenko@ukr.net

Біотехнологічне очищення стічних вод більшості підприємств, в складі яких присутні токсичні фенольні сполуки, на сьогодні $є$ найприйнятнішим способом. Тому пошук нових непатогенних біохімічно активних мікроорганізмів - деструкторів фенолу і їх ідентифікація $\epsilon$ актуальною. Метою роботи було визначення фенолокислювальної активності і профілю жирних кислот Brevibacillus centrosporus F14 - деструктора фенолу, виділеного із стічних вод фармацевтичного заводу. Аналіз жирних кислот культури мікроорганізму проводили з використанням автоматичної системи ідентифікації мікроорганізмів MIDI Sherlock на основі газового хроматографа Agilent 7890. Оцінку фенолокислювальної 
активності бактерій визначали фотометричним методом за ступенем вилучення фенолу з води. Експериментально підтверджено, що штам Brevibacillus sp. F14 виявляє фенолдеструктивну активність. За обробки фенолвмісної води вільними клітинами Brevibacillus sp. F14 концентрація фенолу у воді зменшувалася з 200,0 $\pm 12,0$ до $6,8 \pm 0,8$ мг/л 15-денної експозиції. Хроматографічний аналіз показав, що в профілі жирних кислот досліджуваного штаму переважали насичені жирні кислоти i-14:0 (14.9\%), i-15:0 (14.8\%), a-15:0 $(34.9 \%)$, i-16:0 (11.10\%). Сумарний вміст насичених жирних кислот розгалуженої будови i-14:0, i-15:0, a-15:0, i-16:0, i-17:0, a-17:0, $\Sigma($ a-17:1/i-17:1) становив $85 \%$, а насичених і ненасичених жирних кислот нормальної структури - 7\% від загального пулу жирних кислот. Відмінностями жирнокислотного профілю досліджуваного нами штаму Brevibacillus centrosporus F14 від інших бактерій роду Brevibacillus $є$ наявність значної кількості жирних кислот і-14:0 (14,85\%), i-16:0 (11,10\%), 16:1 w7c alcohol (7,71\%), а також мінорна кількість маркерних жирних кислот $16: 0 \mathrm{~N}$ alcohol $(0,60 \%), 18: 3 \mathrm{w} 6 \mathrm{c}(0,4 \%)$ та $\Sigma(\mathrm{a}-17: 1 /$ i-17:1) (1,94\%). За фенотиповими ознаками і складом жирних кислот досліджуваний фенолокислювальний штам належить до виду Brevibacillus centrosporus. Індекс подібності жирнокислотного профілю штаму Brevibacillus centrosporus F14 3 бібліотечними становить 0,645.

Кл ючов і слова: Brevibacillus centrosporus, деструктор фенолу, ідентифікація, склад жирних кислот.

\section{References}

1. Panda AK, Bisht SS, DeMondal S, Kumar NS, Gurusubramanian G, Panigrahi AK. Brevibacillus as a biological tool: a short review. Antonie Van Leeuwenhoek. 2014; 105(4): 623-639.

2. Zheng L, Yi Y, Liu J, Lin X, Yang K, Lv M, Zhou X, Hao J, Liu J, Zheng Y, Sun M. Isolation and characterization of Marine Brevibacillus sp. S-1 collected from South China Sea and a novel antitumor peptide produced by the strain. PLoS One. 2014; 9(11): e111270.

3. Khalil AB, Sivakumar N, Arslan M, Saleem H, Qarawi S. Insights into Brevibacillus borstelensis AK1 through whole genome sequencing: a thermophilic bacterium iolated from a hot spring in Saudi Arabia. Biomed Res Int. 2018; 2018: Article ID 5862437.
4. Romana S, Hasnaeen AH. Isolation, identification and characterization of AZO dye reactive Violet 5R degrading bacterial strains from the textile sludge. J Bangladesh Acad Sci. 2018; 41(2): 136143.

5. Vasyurenko ZP, Frolov AF. Fatty Acid composition of bacteria as a chemotaxonomic criterion. J Hyg Epidemiol Microbiol Immunol. 1986; 30(3): 287-293.

6. Safronova LA, Zelenaa LB, Klochko VV, Avdeeva LV, Reva ON, Podgorskyi VS. Genoand phenotypic characteristic of Bacillus strains - components of endosporin. Mikrobiol Zhurn. 2012; 74(5): 55-65. (In Russian).

7. Sasser M. Identification of bacteria by gas chromatography of cellular fatty acids. MIDI Technical Note 101. 1990.

8. Logan NA, Forsyth G, Lebbe L, Goris J, Heyndrickx M, Balcaen A, Verhelst A, Falsen E, Ljungh AI, Hansson HB, De Vos P. Polyphasic identification of Bacillus and Brevibacillus strains from clinical, dairy and industrial specimens and proposal of Brevibacillus invocatus sp. nov. Int $J$ Syst Evolut Microbiol. 2002; 52(Pt 3): 953-966.

9. Gorshkova OG, Shtenikov MD, Korotaeva NV, Voliuvach OV. Features of fatty strength profile of strain Brevibacillus centrosporus F14 destructor of phenolic compounds. Ukr Biochem J. 2018; 90(3): 134.

10. Tsubouchi T, Mori K, Miyamoto N, Fujiwara Y, Kawato M, Shimane Y, Usui K, Tokuda M, Uemura M, Tame A, Uematsu K, Maruyama T, Hatada Y. Aneurinibacillus tyrosinisolvens sp. nov., a tyrosine-dissolving bacterium isolated from organics- and methane-rich seafloor sediment. Int J Syst Evol Microbiol. 2015; 65(Pt6): 1999-2005.

11. MIS Operating Manual. www.midi-inc.com, September 2012.

12. Lur'e JuJu. Analytical chemistry of industrial wastewater. M.: Khimija, 1984. 448 p.

13. Bergey's Manual of Systematic Bacteriology. Brenner DJ, Krieg NR, Staley JT, Garrity GM. N.Y.: Springer, 2005; (2): 1108.

14. Kim MK, Sathiyaraj S, Pulla RK, Yang DC. Brevibacillus panacihumi sp. nov., a betaglucosidase-producing bacterium. Int $J$ Syst Evol Microbiol. 2009; 59(Pt 5): 1227-1231.

15. Goto K, Fujita R, Kato Y, Asahara M, Yokota A. Reclassification of Brevibacillus brevis strains 
NCIMB 13288 and DSM 6472 (=NRRL NRS887) as Aneurinibacillus danicus sp. nov. and Brevibacillus limnophilus sp. nov. Int J Syst Evol Microbiol. 2004; 54(Pt 2): 419-427.

16. Takebe F, Hirota K, Nodasaka Y, Yumoto I. Brevibacillus nitrificans sp. nov., a nitrifying bacterium isolated from a microbiological agent for enhancing microbial digestion in sewage treatment tanks. Int J Syst Evol Microbiol. 2012; 62(Pt 9): 2121-2126.

17. Baek SH, Im WT, Oh HW, Lee JS, Oh HM, Lee ST. Brevibacillus ginsengisoli sp. nov., a denitrifying bacterium isolated from soil of a ginseng field. Int J Syst Evol Microbiol. 2006; 56(Pt 11): 2665-2669. 